\title{
Creativity and Security as a Cultural Recipe for Entrepreneurship
}

\author{
(forthcoming in Journal of Institutional Economics)
}

TOMASZ MICKIEWICZ

Aston Business School, Aston University, Aston Triangle, Birmingham B4 7ET, UK. Email: t.mickiewicz@aston.ac.uk

\section{ANNELI KAASA}

School of Economics and Business Administration, University or Tartu, Narva mnt 18, 51009 Tartu, Estonia.Email: anneli.kaasa@ut.ee.

This work was supported by the Estonian Research Council Grant PRG380. We also express gratitude to the editor and the reviewers of this journal, Anna Grosman, Johannes Kleinhempel, and participants of seminars at Aston University, Birkbeck College, Syracuse University, Tartu University, and AOM conference in Boston, for comments and feedback.

\begin{abstract}
We posit that societal cultural values of creativity and security are associated with the likelihood that a person will engage in a business start-up. Creativity supports the opportunity identification and security the opportunity exploitation aspects of entrepreneurship. In contrast, both emphasis on performance and acceptance of risk-taking may not play the role that is typically assumed. To verify our hypotheses we construct a multilevel dataset, combining Global Entrepreneurship Monitor individual-level data with country-level data from the World Values Survey. We use multilevel logit model to address the hierarchical structure of our data. We find that odds of start-up engagement are higher if people in a society value security, yet also appreciate thinking up new ideas and being creative. Our results support McCloskey's distinction between aristocratic and bourgeois values, and John and Storr's proposition that different cultural traits support different aspects of entrepreneurship.
\end{abstract}


"Do you want to test whether a people is given to industry and commerce? Do not sound its ports, or examine the wood from its forest or the produce of its soil. The spirit of trade will get all those things and, without it, they are useless."

(Alexis de Tocqueville, 1958 [1835]: 116)

\section{Introduction}

De Tocqueville (1958 [1835]: 116) identified 'courage to seek prosperity' and 'a sense and habit to find it', combined with 'the assurance of reaping the benefit', as the key elements of the 'spirit of trade'. ${ }^{1}$ Thus, he argued that it is not so much endowment in the material factors of production that results in entrepreneurship, but rather cultural values. This approach is consistent with the recent argument of McCloskey $(2006 ; 2010 ; 2016)$, who posits that innovation and entrepreneurship has been driven by cultural values. ${ }^{2}$ Yet, what exactly are these entrepreneurial values?

To answer this question we rely on the key insight proposed by John and Storr (2018): different aspects of entrepreneurship are supported by different cultural elements. In particular, entrepreneurial process can be conceptualised as including opportunity identification and opportunity exploitation as two indispensable, core elements (Ibid.). We will argue that these two elements of entrepreneurship are correspondingly supported by cultural elements of creativity and security that reflect what Tocqueville highlighted as 'courage and habit to seek', and 'the assurance of reaping the benefits'.

What we argue is that the cultural recipe for entrepreneurship is complex and contains different elements. Intriguingly, we find ourselves in agreement with the intuitions that Tocqueville (1958 [1835]) presented almost two hundred years ago: for entrepreneurship we need

\footnotetext{
${ }^{1}$ In contemporary theory, the concept of 'spirit' remains the key one in Storr's (2004; 2013) and Storr and John's (2020) systematic presentation of the Austrian School approach to culture: 'A spirit in this context refers to a society's ethos or its character, the shared values that motivate, orient and drive people in a society as they go about their lives' (Ibid.: 12). It also remains central to McCloskey $(2006 ; 2010 ; 2016)$, who first systematises normative dimensions of culture and next applies those to historical analysis. However, see also critical discussion in Greif and Mokyr (2016; 2017).

${ }^{2}$ While McCloskey takes central stage here, there are others. Mokyr (2017) offers a further review.
} 
courage and willingness to explore, combined with a sense of confidence that the benefits were there to be reaped.

While we will focus on culture we will not deny the role of institutions. In the long historical perspective both can be seen as interdependent (Greif and Tabellini, 2017). However, as we will discuss, we feel that the role of institutions supporting entrepreneurship is by now well understood (Estrin, Mickiewicz, and Stephan, 2016). In contrast, the role of cultural values remains disputed (Storr and John, 2020).

We start this paper by outlining the concept of cultural values. Next comes the core of the paper, where we propose the values that are conducive to entrepreneurship, relating them to the two elements of the entrepreneurial process we highlighted above (John and Storr, 2018), with supporting arguments. In the empirical section, we introduce our data and methods. We will explain how we constructed a multilevel data set to test our hypotheses, combining Global Entrepreneurship Monitor data with information extracted from the World Values Survey. Next, we will discuss the results, including extensions for more specific forms of entrepreneurship, before presenting our conclusions, pointing to limitations, and suggesting avenues for further work in this area.

\section{Theoretical overview}

\subsection{Cultural values}

The term 'culture' can be understood in different ways, depending on the context, and whether the framework is taken from the fields of sociology, anthropology, linguistics, or humanities. In this paper, the notion of culture derives from sociology and is defined as a pattern of shared values, beliefs, and behaviour of a group of people - these elements are repeated in 
various definitions, see for example: Hall (1980), Chanchani and Theivanathampillai (2002), and Taras, Rowney, and Steel (2009). We tweak the definitions of Hofstede (1980) and Schwartz (2011) to posit that culture is something that provides mental patterns, ways for people to arrange their minds. Culture relates to those aspects of personal values, beliefs and norms of behaviour that are shared within a given social environment. While we will focus on values, these interact with beliefs systematically, and both elements can be seen as part of decision-making heuristics; utilising the latter, people save on the cost of obtaining and analysing information (Alesina and Giuliano, 2015). This decision-making heuristics shapes behaviour. McCloskey (2006), in her work on the cultural traits that matter for business and entrepreneurship, reintroduces the classic concept of virtue, within which values and related behavioural predispositions are seen to be coherent cultural traits. However, while we will draw upon McCloskey (2006), we will not use that term since recent literature gives it a narrower connotation (Newstead et al., 2018).

There are three channels along which culture may affect economic behaviour, including entrepreneurship. First, culture has direct motivational effect through internalised norms (Pitlik and Rode, 2017). For example, trivially, in a country characterised by individualistic values, there will be more people holding these values as their own.

This mean effect however does not imply uniformity in values at the individual level. For example, a person may be inclined to risk taking despite being surrounded by a generally riskaverse society, or maybe even because of it, seeing potential gains from boldness to take risks in a risk-averse society. Yet in such 'incompatible' environments, a person's entrepreneurial activity may be hampered by the fact that he/she will find difficult to secure business cooperation from those who do not share his/her values. It is how personal enforcement associated with societal cultural values work (Greif and Tabellini, 2017; see also: Schwartz, 2006). This relates also to 
business behaviour; as Langlois (2016:3) argues: 'in any culture that fails to validate commercial activity, people will want to better their conditions but culture will strongly discourage or even prevent them from doing so.' In contrast, and applying Davidsson's (2016) terminology, we may say that culture becomes an 'external enabler' of entrepreneurship if the corresponding values are conducive to it, ensuring cooperation of others that is essential for the successful implementation of the entrepreneurial projects. As observed by Krueger, Liñán, and Nabi (2013: 705): 'Two identical people (same experiences, perceptions and preferences) are likely to behave differently if they are under different cultural pressures.' Similarly, Wennberg, Pathak and Autio (2013) notice: 'individuals consider not only their own ability to succeed and the possibility of failure, but also how this action is consistent with prevailing cultural norms and practices' (Ibid.: 758). More specifically, Chamlee-Wright (1997) argues that persuasion is critical to entrepreneurship. 'For an entrepreneurial venture to get off the ground, the entrepreneur must persuade investors that his or her ideas are profitable ones, and consumers that the new or product or service is a desirable one' (Ibid.: 47). Yet, that implies shared meaning and values; that is: culture. If entrepreneurial action is not culturally valued, and therefore not at the centre of cultural meaning, the entrepreneur will find it more difficult to persuade others to secure cooperation she/he needs. This is the second, social channel, along which culture affects entrepreneurship.

Third, culture may influence economic behaviour through the intermediation of formal institutions (Pitlik and Rode, 2017). In the long run it is likely that the institutional set-up representing impersonal enforcement affects cultural norms (Greif and Tabellini, 2017). However, recent empirical work finds that culture has more significant impact on formal institutions compared to vice versa. In particular, Gorodnichenko and Roland (2017) document this in the context of the individualist-collectivist cultural traits as pitched against institutions. This 
perspective is consistent with the theory framework that stresses culture as more fundamental to formal institutions (Williamson, 2000). However, that does not imply that institutions have no independent effect. Both culture and institutions, while not static, are persistent (Greif and Tabellini, 2017), and this implies that in a short run we focus upon, they may both have an independent effect on entrepreneurship.

Culture is more than values, and complete understanding of culture is impossible without ethnographic and anthropological studies. As argued by Lavoie (1991: 34): 'Culture is to be understood broadly as the complex of meanings that allows us to comprehend human action'. By focusing on values, we abstract and ignore a lot that is significant (Heine, 2020). What we gain however is a possibility of quantifiable broad cross-cultural comparisons. For that purpose, cultural values are typically measured by aggregating up survey instruments to the level of countries (or in some cases: regions), with World Value Survey being the most popular source of empirical material recently (Alesina and Giuliano, 2015). The literature proposes different sets of cultural dimensions, such as those of Parsons and Shils (1951), Kluckhohn and Strodtbeck (1961), Hofstede (1980), Schwartz (1994), Trompenaars and Hampden-Turner (1997), Inglehart and Baker (2000) and House et al. (2002). There is already rich empirical literature that connects culture and entrepreneurship (Stephan and Uhlaner, 2010; Taylor and Wilson, 2012; Valdez and Richardson, 2013; Wennberg, Pathak, and Autio, 2013; Thai and Turkina, 2013; Liñán and Fernández-Serrano, 2014; De Clercq, Lim, and Oh, 2014; Minola, Criaco, and Obschonka, 2016; Stephan and Pathak, 2016). However, this literature typically uses composite cultural measures derived empirically from factor analysis. We argue that these techniques combine elements that have conflicting impacts on entrepreneurship into aggregate dimensions. This is consistent with the more general criticism expressed by Hayton and Cacciotti (2013: 715) who observe 'that such 
clustering loses theoretical meaning and empirical information'. Thus, our approach differs. To borrow an expression from Heine (2020), our objective will be to try to unpack the composite; in our case, proposing the elements that we expect to matter most for entrepreneurial activities.

2.2. Which values matter for entrepreneurship?

We argue that the key societal cultural values that matter for entrepreneurship are security and creativity. In so doing, we primarily build on McCloskey's (2006, 2010, 2016) work on culture $^{3}$ that is also consistent with the dimensions highlighted by de Tocqueville (1958 [1835]: 116). However, we follow Langlois (2016) arguing that while McCloskey focused her intuitions on values related to innovation, we should shift emphasis towards entrepreneurship. Innovation is critical, yet especially in its most radical forms it is often embedded in new ventures as contrasted to its incremental forms characterising old and large corporations (Martin and Mitchell, 1998; Baumol, 2010). ${ }^{4}$

\subsection{1 'The sense and habit to find': thinking up new ideas, creativity}

The major theoretical perspective on entrepreneurship is that of Schumpeter (2008 [1911]). It emphasises the element of novelty: entrepreneurs create something new, they innovate. What we label after John and Storr (2018) as opportunity identification, may be further analytically split

\footnotetext{
${ }^{3}$ We are interested in McCloskey's analysis of culture and cultural values, especially in McCloskey (2006). It is beyond our level of competence to contribute to the discussion on the role of culture in long term development. For a state-of-the-art critical reassessment of the latter see Greif and Mokyr (2016).

${ }^{4}$ We do not claim that entrepreneurship is a necessary condition for innovation, just that the two are related. And again, we have neither competence nor ambition to contribute to the wider discussion on factors of development. Saying that, our own tentative opinion is that entrepreneurship is not the only possible path to development. Consider the two top economic development success stories since mid $20^{\text {th }}$ century: South Korea and Taiwan. In the first case, large organisations played far more significant role than in the second. And Taiwan may be more an exception than a rule in South East Asia. Boettke, Coyne and Leeson (2008) argue that cultural traits are behind dominance of large-scale organisations in Japan, which is another spectacular development story of the $20^{\text {th }}$ century. This links with the issue of managers versus entrepreneurs, to which we will return below.
} 
into opportunity discovery and opportunity creation (Alvarez and Barney, 2007). Both may be seen as the first initial phase of the entrepreneurial process, but need not be. Entrepreneurial opportunities may be created in 'iterative, inductive, incremental decision making', continuously along the process of business venturing and development of the new firm (Ibid:: 17).

Here, the link to values is established by McCloskey $(2010,2016)$; the role of cultural support for innovativeness is probably argued nowhere as strongly as in her work (Mokyr, 2017). While at present, acceptance of creativity, innovation, and change is ubiquitous, we can also argue that societies still differ in the extent to which this value is embedded. Resistance to creativity stems from the fact that it may come at a cost. Innovations lead to development, but this development sometimes happens through ‘creative destruction' (Schumpeter 2008 [1911]) even if this is not always or even not mostly the case. According to McCloskey (2010), who follows Kirzner (1973) here: 'A big or small entrepreneur, encouraged by dignity and enabled by liberty, alertly notices an opportunity, and takes it.' (McCloskey, 2010: 20). The third element - noticing opportunity - is creativity, or 'the sense and habit to find' to use de Tocqueville's (1958 [1835]: 116) expression.

Researchers working in the Austrian tradition recognise the link between entrepreneurship, innovation and change (Foss and Klein, 2012; 2015). Within this tradition, Lavoie (1991: 44) sees entrepreneurial creativity as leading to new meaning and understanding: 'alertness in itself is insufficient to cover all the aspects of entrepreneurship ... creativity and judgment are also involved in entrepreneurship ... a crucial component of judgement and creativity is interpretation'. McCloskey emphasises yet something else; she radically departs from the economics approach, in a sense that she sees innovation as separated from pursuit of material gains (see also: Storr, 2013). In her words: 
'[T]he crux here (I repeat to my economist colleagues) is that a Max U model ... cannot work to explain real innovation. That after all is the central point here - that routine maximisations ... do not explain the modern world. What explains it, as the Austrian economists would put it is discovery. /.../ There is no U to max and no constraint to obey if real discovery is at issue, as against routine exploration for, say, oil.' (McCloskey, 2010: 410).

Thus, creativity renders entrepreneurship. Yet, as observed already by Lavoie (1991), creativity is conditioned by culture:

“Entrepreneurship is not only a matter of opening one's eyes, of switching on one's attentiveness; it requires directing one's gaze ... And this raises the question of what gives a predirectedness to the entrepreneur's vision, of why he is apt to read some things and not others. I submit that the answer to this question is culture.' (Lavoie, 1991: 46)

Creativity as a societal value may be interpreted as an aspect of individualism because it is based on affirmation of intellectual autonomy (Schwartz, 2011), which Pitlik and Rode (2017) interpret as 'self-determination'. Similarly, Bennett and Nikolaev (2020) highlight the link between individualistic culture and innovation. The high values placed on creativity and new solutions increase the probability of new venture creation (Lee and Peterson, 2000). It needs 'the courage to overcome the fear of change, to bear defeat unto bankruptcy, to be courteous to new ideas, to wake up next morning and face fresh work with cheer, resisting the despairing pessimism' 
(McCloskey, 2006: 508). Here we see a further link between creativity and confidence that has been recognised in empirical work as the trait that is characteristically associated with starting new ventures (Kahneman, 2011). High levels of confidence and 'an optimistic temperament ... encourages persistence in the face of obstacles' (Kahneman, 2011: 257). Optimism, innovation, and creativity go hand in hand.

Hence, we posit:

H1: A culture characterised by a high value being attached to creativity implies a higher likelihood of an individual starting a new venture.

\subsection{2 'Assurance to reap the benefits': security}

We now turn to the opportunity exploitation. Security of property rights is a recurring theme in the entrepreneurship research, and empirical results confirm the importance of strong property rights (seen as a component of the rule of law) for entrepreneurship (Levie and Autio, 2011; Estrin, Mickiewicz, and Stephan, 2016). ${ }^{5}$ This is because entrepreneurship, especially in the Austrian Economics tradition, is seen as a form of investment, where the human and financial resources of the owner-manager become tied to the new venture (Mises, 1966; Harper, 2003; Foss and Klein, $2012 ; 2015)$. The value of this investment depends on a future flow of returns that may materialise as a slow trickle and only after a considerable delay. For this reason, confidence in the medium to long-term security of property rights is an important external enabler of entrepreneurship.

In the extant research, security is considered in the context of institutions rather than that of culture (Levie and Autio, 2011; Estrin, Mickiewicz, and Stephan, 2016). Security of property

\footnotetext{
${ }^{5}$ Not however that in some societies property rights may be defined and enforced without a foundation of rule of law (Grube 2015; Acemoglu and Robinson, 2019).
} 
rights is viewed as the most business-relevant component of the rule of law, albeit other aspects of the rule of law also matter for entrepreneurship and some may be even more fundamental (such as, for example, personal security as defined by the Habeas Corpus Act). Generally, entrepreneurs need to experience security; this, within the realm of institutions, is delivered by effective constraints imposed on the executive branch of the government, particularly by the independent judiciary (North and Weingast, 1989; Acemoglu and Johnson, 2005; Greif and Mokyr, 2016).

Yet, formal institutions remain effective only as long as there is cultural support for the values and behaviours that sustain them. As Chamlee-Wright (1997) observes:

'Police and court systems would be incapable of enforcing property rights and contracts, for instance, if most members of a society did not accept the legitimacy of the institutional rules. Such acceptance comes not from social contracts devised in the abstract, but through an evolutionary process within the culture of a community.' (Ibid.: 24)

Thus, the security of entrepreneurial investments depends not only on formal institutions but also on social values embedded in culture. Furthermore, the latter may play a role independently of formal institutions. This is easy to see in countries, where much entrepreneurship simply happens outside the formal sector. In this case, security is provided by nothing more than informal norms and culture (De Soto, 1989).

Thus, regardless of the shape of the institutions, culture matters. One may say that property rights are as secure as the people in the neighbourhood accept them to be. The same relates to personal security and other aspects of human rights. Before we encounter government, we encounter our neighbours (Acemoglu and Robinson, 2019), and it matters what their values are. 
As McCloskey (2006: 479) observes: 'economies grow slowly - or not at all - when stealing ... becomes a simpler way to wealth than working and selling'. This is akin to what Storr (2004) identified in his economic ethnography as the contrast between the 'spirit of piracy' and the 'spirit of enterprise'.

Furthermore, pirates when settled become aristocrats, and McCloskey (2006) distinguishes two types of respect for property: one inherent to the aristocratic set of values, and one that is part of the domain of bourgeois virtues. For the aristocracy, the stress is on inheritance, while in the bourgeois set of values 'it is bound up ... with a vision of freely chosen work ... the bourgeois thinks of himself as entrepreneurial' (McCloskey, 2006:). In the latter case, security relates to the 'finding and keeping' component, which is crucial to entrepreneurship (Kirzner, 1989; Harper, 2003).

What we see here is security that is reciprocally offered within a community, out of mutual respect, and includes both personal security (e.g. freedom from assault) and the securing of assets. Both create space for entrepreneurship, and what follows is that respect for the security of others is a cultural value that has a deeply social character. That is, respect for property is always associated with societal bounds, participation, identification with a group. Mutually granted security is related to the emphasis on the reciprocal respect.

Let us now discuss a counter-argument that would suggest that cultural value of security may have a negative impact on entrepreneurship. Cultures strong in emphasis on feeling secure (collectively granted), might also emphasise the need to do things in the way they are 'normally' done. This latter aspect links with security but means that there will be less social support for starting a new business (Russell, 2004; Mueller and Thomas, 2000). 
To solve this difficulty, we apply McCloskey's (2006) terminology with respect to security. Where the aspect of tradition prevails, we are in the realm of aristocratic values. In contrast, entrepreneurship-friendly bourgeois values will stress security granted to those who create something new by their own efforts. In that case, as has been pointed out by Kaasa and Vadi (2010), while people tend to value security, this bourgeois value form part of a strong system of norms that offers support and security to potential and active entrepreneurs. Hence, we formulate our second hypothesis.

H2: A culture characterised by a high value being attached to security implies a higher likelihood of an individual starting a new venture.

To summarize, we follow McCloskey (2006) in arguing that an entrepreneurship-friendly culture is a complex phenomenon, where different, even apparently divergent values, need to be present. Cultural affirmation of creativity supports opportunity discovery and creation. Security, both personal and of property resulting from entrepreneurial action, supports opportunity exploitation. Both therefore create a cultural recipe for entrepreneurship.

\section{Data and Methods}

\subsection{Data, variables}

To test our hypotheses, we use a large dataset constructed by combining information from the Global Entrepreneurship Monitor (GEM), with country-level data added from the World Value Survey (WVS), World Bank, and the Polity project. The GEM project utilizes harmonized cluster sampling, normally of at least 2,000 working age individuals per country, to identify new 
entrepreneurs. It measures different aspects of entrepreneurship and the related characteristics of individuals (Reynolds et al., 2005). GEM provides an internationally comparable dataset that is widely used as a source of data for multilevel entrepreneurship research (e.g. Estrin, Mickiewicz, and Stephan, 2016; Lim, Oh, and De Clercq, 2016; Schillo, Persaud, and Jin, 2016). The sampling procedure is reviewed by Reynolds et al. (2005). As argued by Davidsson (2016: 207), today the GEM project 'provides the knowledgeable user with a unique and high quality data set' enabling a cross-country comparison of entrepreneurship.

\subsubsection{Dependent variable}

We use the GEM measure of the nascent entrepreneur as our dependent. It is an indicator variable that takes the value of 1 if the GEM questionnaire-defined criteria are met. These criteria focus on individuals who moved from having a new business idea to taking concrete steps to start a new venture: the business has not been operational for more than three months, that is, it has not yet transferred from the nascent start-up phase to the new business phase. For further details on how this variable is constructed see Reynolds et al. (2005). Nascent entrepreneurship is a popular dependent variable in the empirical literature because it suffers less from either endogeneity visà-vis some of the characteristics of individuals or from selection bias.

We drew our sample from every country surveyed in GEM that had data available at the time of writing. Therefore, our starting point is an unbalanced multilevel cross-country panel data of individuals for the period 2001-2015. However, the set of observations we could use was limited with the availability the country level data on values based on the WVS, as we will explain below. As a result, in our regressions we utilise 2005-2015 data. 


\subsubsection{Core independent variables and culture-related controls}

Our hypotheses relate to the impact of societal values on entrepreneurship. The measures of various values are taken from the World Values Survey (WVS, 2015), which is the most popular source of data on cultural values (Alesina and Giuliano, 2015). We picked questions from the reduced Schwartz Value Inventory included only in waves 5 (2005-2009) and 6 (2010-2014) of this multi-country survey with 7 waves since 1981. First, in order to address creativity (Hypothesis 1), we use the question about the importance of thinking up new ideas and being creative. Next, for (bourgeois) security we included the question about the importance of living in secure surroundings. We take it as being the most closely correlated to our arguments in Section 2.2.3 above, and we will use it to test Hypothesis 2. However, to alleviate concerns about omitted variable bias, we included importance of always behaving properly, and importance of tradition (both related to the aristocratic dimension of security), accepting risks, striving for wealth and success, importance of being rich, importance of being very successful, importance of having good time, and finally importance attached to the environment.

As the aim was to analyse the impact of the cultural environment on entrepreneurship, the cultural variables were included at the country level. Hence individual-level variables from WVS were aggregated by calculating the country means, using the weights provided by the WVS, which is a standard approach in constructing cultural values (Alesina and Giuliano, 2015; Pitlik and Rode, 2017). When merging data from WVS with GEM data, we matched the GEM individual data with WVS indicators from the same year or up to two years previously, where this was available (depending on the year the particular WVS wave was implemented in a country). If the gap between the GEM observations and the available WVS data was three or more years we did not make a match. Exact mapping is available on request. 


\subsubsection{Other controls}

Alongside culture, constitutional level institutions especially are characterised by considerable inertia over time, and to stack odds against our tests we control for effective constraints on the executive power of government (North and Weingast, 1989; Acemoglu and Johnson, 2005; Greif and Mokyr, 2016). In particular, higher levels of constraints include the power of a strong and independent judiciary system to put on hold any abuse of power by the executive. Recent examples of the use of this indicator in empirical research on entrepreneurship and institutions include Estrin, Mickiewicz, and Stephan (2013; 2016), Estrin, Korosteleva, and Mickiewicz (2013), Estrin et al. (2019), and, running parallel, Besley and Mueller (2018) for FDI. The executive constraints is formal institutions' counterpart to the cultural value of security (Hypothesis 2), as it controls for constitutional conditions protecting property rights. It is taken from the Polity project (Marshall, Jaggers, and Gurr, 2010) ${ }^{6}$.

On the regulatory level of institutions we include an index that is most directly related to start-up activities, that is Business Freedom, taken from the Economic Freedom dataset offered by the Heritage Foundation and Wall Street Journal project. It weights equally 13 indicators from World Bank 'Doing Business' set: 4 source indicators relate to starting a business, 3 to obtaining licence, 3 to closing a business (which may affect entry decisions via value of real options), and 3 to getting electricity connected. All these are integrated into one index (The Heritage Foundation, 2020).

The entrepreneurial entry decision is not only influenced by institutions but also by other environmental (country) level features, and by the characteristics of individuals. We include the

\footnotetext{
${ }^{6}$ Munck and Verkuilen's (2002) comparative analysis of the quality of constitutional indicators, recommend the Polity project as a superior data source.
} 
level of development (and its square term, to allow for nonlinearity), which may affect attractiveness of entrepreneurship (Estrin et al., 2019). It is proxied by GDP per person, purchasing power parity, constant prices (from World Bank). In addition, we include unemployment, which may have either a push (necessity) or discouraging (lower opportunities) effect on entrepreneurship (Parker, 2018), also from World Bank.

We use indicators from the GEM survey to control for individual characteristics. We include an individual indicator variable that represents the respondent's involvement in another established business (for serial entrepreneurship); the indicator variables that represent a business discontinued in the last 12 months; experience of acting as a business angel in the past 3 years; age and age squared; gender; and educational achievement categories. This set of control variables is consistent with other studies on institutions and entrepreneurship (e.g. Estrin, Mickiewicz, and Stephan, 2016). In GEM data we also have two variables that correspond to fear of failure, and to the level of confidence in one's own entrepreneurial skills. These are useful individual-level controls when placed alongside societal level cultural indicators as described above. Both raise the

threshold for confirming Hypothesis 1, as they control for the impact of personal traits related to self-direction (Pitlik and Rode, 2017) that were internalised.

Table 1 below presents a list of the variables used in this study and their description and sources, and contains descriptive statistics. A correlation table is available on request. $\{$ Table 1$\}$

\subsection{Estimation strategy}

We use multilevel modelling to address the hierarchical structure of our data, with observations on individuals at the lower level and country-years representing the higher level. This structure 
implies that the individual observations are not independent. Failure to account for this would lead to biased results (Hox, Moerbeek, and van de Schoot, 2017). Regressing individual outcomes on country level values also alleviates concerns about reverse causality (Pitlik and Rode, 2017). We follow Cameron and Miller (2015) recommendation for modelling standard errors for multilevel discrete choice models based on the exchangeable covariance matrix. This accounts for within cluster correlations between observations; in our case clusters are country-years subsamples.

Following the standard routine, we first estimate the intercept only (empty) model. Next, we add our explanatory variables, as discussed above, and employ the full random intercept model. After that we consider random coefficient (slope) models, which allow for the coefficient(s) of some variables to vary randomly across country-year groups. More specifically, we tested whether the impact of entrepreneurs' age, education, and gender on the likelihood of being engaged in new business creation is the same across country-year groups by introducing random coefficients for these variables. We focus on these characteristics of individuals as they are seen to be core determinants of entrepreneurship (Parker, 2018), and we also consider them to be related to how the individuals are affected by culture. By experimenting with these alternative models, we develop an understanding of how robust the results are and how sensitive they are to alternative methods of estimation. Our random intercept model, which utilizes all the explanatory variables discussed earlier, is specified as follows:

Startup $_{i j}=\beta_{0}+\beta_{1}$ Age $_{i j}+\beta_{2}$ Age_squared $_{i j}+\beta_{3}$ Male $_{i j}+\beta_{4}$ Educ $_{-}$primary $_{i j}+\beta_{5}$ Educ_some sec ond $_{i j}$ $+\beta_{6} E d u c \_s e c o n d_{i j}+\beta_{7}$ Med_income $+\beta_{8} H_{\text {High_income }}+\beta$ Estab_bus $_{9 i j}+\beta_{10}$ Discontinued_bus $_{i j}$

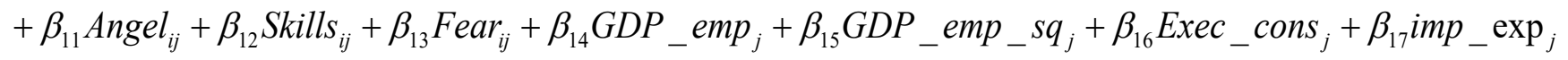
$+\beta_{18}$ Security $_{j}+\beta_{19}$ Behaving $_{j}+\beta_{20}$ Tradition $_{j}+\beta_{21}$ Risk $_{j}+\beta_{22}$ Wealth $_{j}+\beta_{23}$ Success $_{j}+\beta_{24}$ Creativity $_{j}$ $+u_{j}+\varepsilon_{i j}$ 
where Startup $i j$ is our GEM-based indicator of being involved in new venture creation; variables with subscripts $i j$ represent individual-level direct effects; variables with subscripts $j$ represent country-year effects; the random intercept in the equation is represented by $u_{j}$, with $\varepsilon_{i j}$ representing individual-level residuals. In turn, the random coefficients models (not spelled out for brevity) will have random slopes of the variables we discussed in the random part of the model.

Given that our dependent variable is binary, we apply a logit estimator. Values reported in Table 2 are odds ratios (obtained by exponentiating both sides of the equation) instead of raw logit coefficients, thus facilitating interpretation and enabling immediate evaluation of the size of the effects by the reader. In that form, the model is interpreted as multiplicative. For a unit change in any independent variable, the odds ratio changes by a factor reported for that variable in Table 2 below. Where an independent variable is a dummy, the reported value shows how much larger being in that category makes the odds ratio of nascent entrepreneurship compared with the benchmark category. For all types of variables, if the value reported is one, the given variable has no impact on the odds ratio of nascent entrepreneurship involvement. A value below one implies a negative impact; and above one, a positive impact (e.g. Long and Freese, 2014). The values in brackets are exponentiated standard errors.

\section{Results and Discussion}

\subsection{Core Results}

Table 2 presents the results.

$\{$ Table 2$\}$

Hypothesis 1 appears to be strongly supported by the results: if thinking up new ideas and being creative is valued in a society, the odds of starting a business are high. We can evaluate the 
magnitude of this effect by multiplying the odds ratio by the exponential function of standard deviation (Long and Freese, 2014) to obtain change in odds for one standard deviation change in the country creativity score. It comes as tangible 2.2 (based on Model 1). Likewise, with respect to Hypothesis 2, high value placed on security in the society shows a strong relationship with the odds of people being engaged in a start-up, consistent across the models. Interestingly, again evaluating the magnitude of this effect using the same method as before we get the change triggered by move by one standard deviation to be almost the same as in the previous case that is about 2.2 (as here while the odds ratio is lower, this is counterbalanced by higher standard deviation).

Thus, the hypotheses are supported.

At the same time the importance given to tradition, and to behaving properly in a society, appear to have no significant association with the odds of engaging in a start-up. This provides support for the distinction between the aristocratic values focused on tradition and entrepreneurship-friendly bourgeois values emphasising granting security for those putting their own effort for creating something new, as discussed in Section 2.2.2. The latter correlate with entrepreneurship, but not the former.

Being able and willing to cope with risks and uncertainty has been seen as a key entrepreneurial trait since the argument was presented by Knight (2009 [1921]). While the willingness to accept uncertainty may be represented as courage, risks can be insured against. Previously, Koudstaal, Sloof, and Van Praag (2016) have found entrepreneurs having similar risk aversion levels compared to managers. The evidence we obtained regarding the societal value of taking risks is mixed at most. The statistical significance is confirmed in just one model and not in others. Here, we may also face the problem that the question combines two somewhat different 
aspects of values: adventure and taking risks. Adventure may pertain to a hedonistic aspect of culture.

The importance of being very successful in a society turned out to be not significant for the probability of starting a new business. Emphasis on wealth (and more widely: performance) in a society could mean that the achievements related to entrepreneurial activity are highly respected. On the other hand however, appreciation of wealth may not be the value that differentiates those who are engaged in new business venturing from those who take some well-rewarded employee jobs in business. It seems that our results are more consistent with the latter view. In the case of success and wealth motivation (performance orientation) entrepreneurship may not be perceived as the best way of achieving it. Climbing up the ladder of managerial positions within a large organisation may be a better strategy in this case (Hofstede, Hofstede, and Minkov, 2010).

If we follow Teague, Storr, and Fike (2020: 2) and define materialism as 'desires to acquire material possessions for oneself above most other things', then the 'importance of being rich' is a good measure of materialism. While, our results cannot refute the proposition that it remains central for economic activity, what we see is that it is not specifically associated with entrepreneurship, again arguably because there are ways to get rich within extant organisations, and alternative paths to wealth. We may also notice the results on materialism that Teague, Storr, and Fike (2020) obtained. The evidence they provided suggests that countries that embrace markets therefore creating conditions conducive to entrepreneurship are less not more materialistic. Their stronger result is consistent with McCloskey's (2010) argument we discussed above: the creative element of entrepreneurship cannot be explained by greed alone.

Developing further the analytical distinctions, we argue that courage and confidence to innovate can be seen as process-oriented values, while wealth and success are values that can be 
viewed as more result-oriented. It might well be that when starting a new business, success is a goal that is too remote to have much initial impact. In contrast, (bourgeois) courage and confidence to innovate are needed right from the very beginning of the process. This reinforces the emphasis that the literature places on entrepreneurship being seen as a process (McMullen, 2015; Davidsson, 2016).

4.2. Extensions: innovative entrepreneurship, high aspirations, business angels, young businesses In the results reported above, our dependent variable is the classic (if narrow) measure of entrepreneurship used in cross-country studies: the likelihood of being involved in a nascent startup project (Davidsson, 2016). However, we conducted several additional experiments utilising alternative entrepreneurship-related measures in order to (i) understand more fully the role of cultural values, (ii) compare our results with earlier work, and (iii) test the robustness of the results. For reasons of space, we briefly discuss these additional results instead of presenting the tables. The tables, data and codes that generated the results are available at the authors' ResearchGate web pages.

These additional tests are as follows. The first derives from a broad stream of research that explores the link between culture and innovation. Shane $(1992,1993)$ made early contributions to this, and recent empirical work includes Kaasa and Vadi (2010), Taylor and Wilson (2012), and meta-analysis by Sarooghi, Libaers, and Burkemper (2015). In the GEM data there are questions that rank the degree of product and process innovation of nascent entrepreneurs. Using a combination of these items, we constructed a scale ordering start-ups according to their degree of innovativeness, and used it as a dependent variable in an ordered logit model (with the same set of independent variables and random effects as in Table 2). Interestingly, the results were entirely 
consistent with Table 2: the cultural factors that correlate with the standard measure of start-up engagement also correlate with entrepreneurship ordered by its innovativeness.

Second, in the entrepreneurship literature, there is an argument that the ambitious, growthoriented forms of entrepreneurship are particularly important. Cross-country studies based on GEM operationalise this with the level of (employment) growth aspirations of entrepreneurs (e.g. Autio and Acs, 2010; Estrin, Korosteleva, and Mickiewicz, 2013). Again, following the same specifications as before, we ran four multilevel count Poisson models, with the GEM measure of expected number of employees in five-years' time taken as the dependent variable, as is used in the extant literature. We found some interesting differences between these and our core results. Secure surroundings as a cultural value turned out to be highly significant, just as it did in our core results, but this time creativity did not. This calls for more exploration, as on the individual level there is evidence on the link between innovation and growth-oriented strategies (Estrin et al., 2020). Next, interestingly, a willingness to take risks was negatively correlated with ambitious entrepreneurship; it is possible that in order to ensure growth, risks have to be rather avoided. In addition, for ambitious forms of entrepreneurship, we now have a significant positive impact of the importance of being very successful. The latter result is intuitive in that the cultural support for business success (performance orientation) provides fertile ground for higher levels of ambition. Thus, while performance-orientation as a societal value does not matter for entrepreneurship overall, it does matter for high growth aspirations ventures.

Third, we explored a different form of entrepreneurship: engagement as an informal investor. This exercise is parallel to work by Li and Zahra (2012) on cultural support for entrepreneurial finance, yet in their case it is represented by venture capital. The GEM question we use as a dependent variable about being an informal investor is backward-looking, and this 
time we therefore dropped the variables representing individual fear of failure and entrepreneurial skills since we would risk simultaneity (endogeneity). The results were somewhat weaker than for our core models, yet in two out of four models we obtained significant results both on creativity and on security. At the same time, the coefficients on cultural support for willingness to take risks turned out to be insignificant, again consistent with our argument on deemphasising the role of risk acceptance. However, here, it may also be that, unlike nascent entrepreneurs, business angels have more opportunity to spread their risks, and these risks are also perceived as being lower thanks to their typically higher wealth position. As a result, risk taking aspect matters less.

Fourth and finally, we replaced the nascent start-up dependent variable with being the owner-manager of a young business (up to 42 months old). As this is, by construction, backwardlooking we avoided simultaneity by omitting the same independent variables that we dropped when testing the business angel dependent variable. This time, a very strong positive result on the cultural value of security dominates the other results. But creativity comes out as insignificant, and support for risk-taking is mostly insignificant as well. This echoes our results on growth aspirations. Again, it appears that creativity is critical in the initial phase of acting on entrepreneurial opportunities (nascent entrepreneurship) but loses impact later in the process. For fully operational young business we also have a clear-cut negative and significant result of tradition-supporting values.

This last experiment deserves attention as it creates an opportunity to extend GEM-based work on the stages of entrepreneurship (e.g. Wennekers et al., 2005; Bergmann and Stephan, 2013; Mickiewicz et al., 2017) where the role of the cultural environment could be hypothesised to change during the entrepreneurial process. As already highlighted, there may be good reasons why support for creativity matter most for nascent businesses and, in contrast, why the societal value 
of security is what becomes critical in the more advanced phase. This theme is worth exploring in further work.

\section{Conclusions}

While preserving the role of individual human agency in the theory of entrepreneurship, we need to account for social environmental influences (Davidsson, 2016), and look beyond the role of institutions, and consider culture (Alesina and Giuliano, 2015; Gorodnichenko and Roland, 2017). We subscribe to entrepreneurial theory built on Austrian Economics with its emphasis on entrepreneurial judgment leading to entrepreneurial action, a prime example of which is new firms creation, the outcome we analyse in this paper. New firms creation process can be presented as consisting of two key elements, opportunity identification and opportunity exploitation (John and Storr, 2018). The first element is supported by creativity. At the same time, the aspect of investment related to start-ups emphasized by Foss and Klein (2015) implies the importance of security, which as we argue is supported not only by institutions but also by cultural values (Chamlee-Wright, 1997).

When considering the role of culture in entrepreneurship, we postulate that using highly aggregated constructs of culture may not suit the purpose when it comes to entrepreneurship (Hayton and Cacciotti, 2013). Instead of matching pre-existing aggregate measures of culture with entrepreneurship, we identify two cultural traits that could be considered to be consistent with entrepreneurial behaviour. This is based on the assumption that 'culture is decomposable' (Mokyr, 2017: 8). In particular our analysis leads us first to stress creativity, an aspect of individualism, akin to Pitlik and Rode (2017) self-direction construct. However at the same time, we supplement it with the second element, security. Thus, we follow McCloskey (2006), arguing that a business- 
and entrepreneurship-supporting culture is a balance of different, sometimes apparently conflicting elements, and the right mixture is not easy to identify. However, the approach proposed by John and Storr (2018) is promising. Here we start with the identification of the key components of the entrepreneurial process and next ask which elements of culture support those.

We conclude that our results are consistent with the thesis that creativity and security form a bundle of cultural ingredients that support entrepreneurship. In contrast, the stress on wealth, success and achievement (performance orientation; materialism) that has been emphasised in the classic entrepreneurship literature (such as by Baumol and Strom, 2007) does not appear to play a role. This seems consistent with results obtained by Teague, Storr, and Fike (2020), as discussed above.

We think there are two explanations of it. First, there are alternative ways to achieve wealth, either within pre-existing business organisations, or sometimes not by value-creation, but by plunder (by piracy, to use Storr's, 2004 terminology); the latter being consistent with aristocratic not bourgeois set of values in McCloskey's (2006) sense, with oligarchic structures as described by Acemoglu and Robinson (2019), and with destructive entrepreneurship in Baumol's (1990) terminology. Second, following McCloskey (2010) we should avoid economic reductionism and see drive to achieve material wealth as one of many and not necessary a dominant cultural value.

Likewise, our results on the affirmation of risk-taking are at best mixed. Risk can be insured against, and the uncertainty-handling aspect seen as core to entrepreneurship is arguably more closely related to innovativeness, and therefore creativity. In that sense the two major entrepreneurship theory traditions, that of Knight (2009 [1921]) stressing uncertainty, and that of Schumpeter (2008) stressing innovation, may be closer to each other than it appears. 
Taken together, this calls for a reconsideration of the basic assumptions about human motivation upon which the classic entrepreneurship theory is built. As we have argued, pursuit of wealth may be common, but is not a feature specific to entrepreneurship, unlike what some of the classic entrepreneurship theory emphasise (Baumol, and Strom, 2007). This is a fundamental reason why the classic economics' approach (based on wealth maximisation) is too narrow to interpret the entrepreneurship phenomena in full.

To conclude, we think that Tocqueville was surprisingly accurate arguing almost two hundred years ago that wealth produced by entrepreneurs is supported by cultural values that combine 'courage to seek' and 'habits to find' with 'assurance of reaping the benefits.'

\section{References}

Acemoglu, D., and Johnson, S. (2005), 'Unbundling Institutions', Journal of Political Economy, 113(5): 949-995.

Acemoglu, D., and Robinson, J. A. (2019), The Narrow Corridor: How Nations Struggle for Liberty, London: Penguin.

Alesina, A., and Giuliano, P. (2015), 'Culture and Institutions', Journal of Economic Literature, 53(4): 898-944.

Alvarez, S. A., and Barney, J. B. (2007), 'Discovery and Creation: Alternative Theories of Entrepreneurial Action', Strategic Entrepreneurship Journal, 1(1-2): 11-26.

Autio, E., and Acs, Z. (2010), 'Intellectual Property Protection and the Formation of Entrepreneurial Growth Aspirations', Strategic Entrepreneurship Journal, 4(3): 234-251.

Baumol, W. (1990), 'Entrepreneurship: Productive, Unproductive and Destructive', Journal of Political Economy, 98(5): 893-921.

Baumol, W. J. (2010), The Microtheory of Innovative Entrepreneurship, Princeton: Princeton University Press.

Baumol, W. J., and Strom, R. J. (2007), 'Entrepreneurship and Economic Growth', Strategic Entrepreneurship Journal, 1(3-4): 233-237.

Bennett, D. L., and Nikolaev, B. (2020), 'Historical Disease Prevalence, Cultural Values, and Global Innovation', Entrepreneurship Theory and Practice, early online.

Bergmann, H., and Stephan, U. (2013), 'Moving on from Nascent Entrepreneurship: Measuring Cross-National Differences in the Transition to New Business Ownership', Small Business Economics, 41(4): 945-959. 
Besley, T. and Mueller, H. (2018), 'Institutions, Volatility and Investment', Journal of the European Economic Association, 16(3): 604-649.

Boettke, P., Coyne, C., and Leeson, P. (2008), 'Institutional Stickness and the New Development Economics', American Journal of Economics and Sociology, 67(2): 331-358.

Cameron, A. C., and Miller, D. L. (2015), 'A Practitioner's Guide to Cluster-Robust Inference'. Journal of Human Resources, 50(2): 317-372.

Chamlee-Wright, E. L. (1997), The Cultural Foundations of Economic Development, London: Routledge.

Chanchani, S., and Theivanathampillai, P. (2002), 'Typologies of Culture'. Department of Accountancy and Business Law Working Papers Series, 04_10/02, Dunedin: University of Otago.

Davidsson, P. (2016), Researching Entrepreneurship, New York: Springer.

De Clercq, D., Lim, D. S. K., and Oh, C. H. (2014), 'Hierarchy and Conservatism in the Contributions of Resources to Entrepreneurial Activity'. Small Business Economics, 42(3): 507-522.

De Soto, H. (1989), The Other Path, New York: Harper and Row.

De Tocqueville, A. (1958 [1835]), Journeys to England and Ireland, New Haven: Yale University Press.

Estrin, S., Korosteleva, J., and Mickiewicz, T. (2013), 'Which Institutions Encourage Entrepreneurial Growth Aspirations?', Journal of Business Venturing, 28(4): 564-580.

Estrin, S., Mickiewicz, T., and Stephan, U. (2013), 'Entrepreneurship, Social Capital, and Institutions: Social and Commercial Entrepreneurship Across Nations'. Entrepreneurship Theory and Practice, 37(3): 479-504.

Estrin, S., Mickiewicz, T., and Stephan, U. (2016), 'Human Capital in Social and Commercial Entrepreneurship', Journal of Business Venturing, 31(4): 449-467.

Estrin, S., Mickiewicz, T., Stephan, U., and Wright, M. (2019), 'Entrepreneurship in Emerging Markets', In: Grosse, R. and Meyer, K. (eds.), The Oxford Handbook of Management in Emerging Markets (pp. 457-494), Oxford: Oxford University Press.

Estrin, S., Korosteleva, J., and Mickiewicz, T. (2020), 'Schumpeterian Entry: Innovation, Exporting, and Growth Aspirations of Entrepreneurs'. Entrepreneurship: Theory and Practice, early online.

Foss, N. J. and Klein, P. G. (2015), 'Introduction to a Forum on the Judgment-Based Approach to Entrepreneurship: Accomplishments, Challenges, New Directions', Journal of Institutional Economics, 11(3): 585-599.

Foss, N. J., and Klein, P. G. (2012), Organizing Entrepreneurial Judgment: A New Approach to the Firm, Cambridge: Cambridge University Press.

Gorodnichenko, Y., and Roland, G. (2017), 'Culture, Institutions, and the Wealth of Nations', Review of Economics and Statistics, 99(3): 402-416.

Greif, A., and Mokyr, J. (2016), 'Institutions and Economic History: a Critique of Professor McCloskey', Journal of Institutional Economics, 12(1): 29-41. 
Greif, A., and Mokyr, J. (2017), 'Cognitive Rules, Institutions, and Economic Growth: Douglass North and Beyond, Journal of Institutional Economics, 13(1): 25-52.

Greif, A., and Tabellini, G. (2017), 'The Clan and the Corporation: Sustaining Cooperation in China and Europe', Journal of Comparative Economics, 45(1): 1-35.

Grube, L. E. (2105), 'The Role of Culture in the Persistence of Traditional Leadership', In: V.H. Storr, V.H. and Grube, L. E. (Eds.), Culture and Economic Action (pp. 375-397), Cheltenham: Edward Elgar Publishing.

Hall, S. (1980), 'Cultural studies: Two paradigms', In N. B. Dirk, and Ortner, S. B. (Eds.), $A$ Reader in Contemporary Social Theory (pp. 520-538), Princeton, NJ: Princeton University Press.

Harper, D. A. (2003), Foundations of Entrepreneurship and Economic Development, Abingdon: Routledge.

Hayton, J. C., and Cacciotti, G. (2013), 'Is there an entrepreneurial culture? A review of empirical research', Entrepreneurship and Regional Development, 25(9-10): 708-731.

Heine, S. J. (2020), Cultural Psychology, New York: Norton.

Hofstede, G. (1980), Culture's Consequences: International Differences in Work Related Values. Beverly Hills, CA: SAGE Publications.

Hofstede, G., Hofstede, J., and Minkov, M. (2010), Cultures and Organizations: Software of the Mind, Boston: McGraw-Hill.

House, R., Javidan, M., Hanges, P., and Dorfman, P. (2002), 'Understanding cultures and implicit leadership theories across the globe: an introduction to project GLOBE', Journal of World Business, 37(1): 3-10.

Hox, J. J., Moerbeek, M., and van de Schoot, R. (2017), Multilevel Analysis: Techniques and Applications, New York: Routledge.

Inglehart, R., and Baker, W. E. (2000), 'Modernization, Cultural Change, and the Persistence of Traditional Values', American Sociological Review, 65(1): 19-51.

John, A., and Storr, V. H. (2018), 'Kirznerian and Schumpeterian entrepreneurship in Trinidad and Tobago', Journal of Enterprising Communities, 12(5): 582-610.

Kaasa, A., and Vadi, M. (2010), 'How Does Culture Contribute to Innovation? Evidence from European Countries', Economics of Innovation and New Technology, 19(7): 583-604.

Kahneman, D. (2011), Thinking, Fast and Slow, London: Penguin.

Kirzner, I. M. (1973), Competition and Entrepreneurship, Chicago: University of Chicago Press.

Kirzner, I. M. (1989), Discovery, Capitalism, and Distributive Justice, Oxford: Blackwell.

Kluckhohn, F. R., and Strodtbeck, F. L. (1961), Variations in Value Orientations. Evanston, IL: Row, Peterson.

Knight, F. H. (2009 [1921]), Risk, uncertainty and profit, Orlando: Signalman.

Koudstaal, M., Sloof, R., and Van Praag, M. (2016), 'Risk, Uncertainty, and Entrepreneurship: Evidence from a Lab-in-the-Field Experiment', Management Science, 62(10): 2897-2915.

Krueger, N., Liñán, F., and Nabi, G. (2013), 'Cultural Values and Entrepreneurship', Entrepreneurship and Regional Development, 25(9-10): 703-707. 
Langlois, R. (2016), 'Institutions for Getting out of the Way', Journal of Institutional Economics, 12(1): 53-61.

Lavoie, D. (1991), 'The Discovery and Interpretation of Profit Opportunities: Culture and the Kirznerian Entrepreneur', In Berger, B. (ed.) Culture of Entrepreneurship (pp. 33-52), San Francisco, CA: ICS Press.

Lee, S. M., and Peterson, S. J. (2000), 'Culture, Entrepreneurial Orientation, and Global Competitiveness', Journal of World Business, 35(4): 401-416.

Levie, J., and Autio, E. (2011), 'Regulatory Burden, Rule of Law, and Entry of Strategic Entrepreneurs: An International Panel Study', Journal of Management Studies, 48(6): 13921419.

Li, Y., and Zahra, S. A. (2012), 'Formal Institutions, Culture, and Venture Capital Activity: A Cross-Country Analysis', Journal of Business Venturing, 27(1): 95-111.

Lim, D. S., Oh, C. H., and De Clercq, D. (2016), 'Engagement in Entrepreneurship in Emerging Economies: Interactive Effects of Individual-Level Factors and Institutional Conditions', International Business Review, 25(4): 933-945.

Liñán, F., and Fernández-Serrano, J. (2014), 'National Culture, Entrepreneurship and Economic Development: Different Patterns Across the European Union', Small Business Economics, 42(4): 685-701.

Long, J. S., and Freese, J. (2014), Regression Models for Categorical Dependent Variables Using Stata, College Station, TX: Stata Press.

Marshall, M., Jaggers, K., and Gurr, T. (2010), 'Polity IV Project: Political Regime Characteristics and Transitions 1800-2010: Polity Level 2004-2008', Retrieved from http://www.systemicpeace.org/inscrdata.html.

Martin, X., and Mitchell, W. (1998), 'The Influence of Local Search and Performance Heuristics on New Design Introduction in a New Product Market', Research Policy, 26(7-8): 753-771.

McCloskey, D. N. (2006), Bourgeois Virtue, Chicago, IL: University of Chicago Press.

McCloskey, D. N. (2010), Bourgeois Dignity: Why Economics Can't Explain the Modern World, Chicago, IL: University of Chicago Press.

McCloskey, D. N. (2016), Bourgeois Equality: How Ideas, not Capital or Institutions, Enriched the World, Chicago, IL: University of Chicago Press.

McMullen, J. S. (2015), 'Entrepreneurial Judgment as Empathic Accuracy: a Sequential DecisionMaking Approach to Entrepreneurial Action', Journal of Institutional Economics, 11(3): 651-681.

Mickiewicz, T., Nyakudya, F. W., Theodorakopoulos, N., and Hart, M. (2017), 'Resource Endowment and Opportunity Cost Effects Along the Stages of Entrepreneurship', Small Business Economics, 48(4): 953-976.

Minola, T., Criaco, C., and Obschonka, M. (2016), 'Age, Culture and Self-Employment Motivation', Small Business Economics, 46(2): 187-213.

Mises, L. V. (1966), Human Action, New York: Basic Books.

Mokyr, J. (2017), A Culture of Growth: the Origins of the Modern Economy, Princeton: Princeton University Press. 
Mueller, S. L., and Thomas, A. S. (2000), 'Culture and Entrepreneurial Potential: a Nine Country Study of Locus of Control and Innovativeness', Journal of Business Venturing, 16(1): 5175.

Munck, G. L., and Verkuilen, J. (2002), 'Conceptualizing and Measuring Democracy: Evaluating Alternative Indices', Comparative Political Studies, 35(1): 5-34.

Newstead, T. P., Macklin, R., Dawkins, S., and Martin, A. (2018), 'What is virtue? Advancing the conceptualization of virtue to inform positive organizational inquiry', Academy of Management Perspectives, 32(4): 443-457.

North, D. C., and Weingast, B. R. (1989), 'Constitutions and Commitment: the Evolution of Institutions Governing Public Choice in Seventeenth-Century England', The Journal of Economic History, 49(4): 803-832.

Parker, S. C. (2018), The Economics of Entrepreneurship, Cambridge: Cambridge University Press.

Parsons, T., and Shils, E. A. (1951), Toward a General Theory of Action, Cambridge, MA: Harvard University Press.

Pitlik, H., and Rode, M. (2017), 'Individualistic Values, Institutional Trust, and Interventionist Attitudes. Journal of Institutional Economics, 13(3): 575-598.

Reynolds, P., Bosma, N., Autio, E., Hunt, S., De Bono, N., Servais, I., Lopez-Garcia, P., and Chin, N. (2005), 'Global Entrepreneurship Monitor: Data Collection Design and Implementation 1998-2003', Small Business Economics, 24(3): 205-231.

Russell, R. D. (2004), 'Cultural Influences on Entrepreneurship', Journal of Transnational Management, 10(1): 37-59.

Sarooghi, H., Libaers, D., and Burkemper, A. (2015), 'Examining the Relationship between Creativity and Innovation: A Meta-Analysis of Organizational, Cultural, and Environmental Factors', Journal of Business Venturing, 30(5): 714-731.

Schillo, R. S., Persaud, A., and Jin, M. (2016), 'Entrepreneurial Readiness in the Context of National Systems of Entrepreneurship’, Small Business Economics, 46(4): 619-637.

Schumpeter, J. (2008 [1911]), The Theory of Economic Development, New Brunswick, NJ: Transaction Publishers.

Schwartz, S. H. (1994), 'Beyond Individualism/Collectivism: New Cultural Dimensions of Values', In U. Kim, Triandis, H. C., Kagitçibasi, Ç., Choi, S. C., and Yoon, G. (ds), Individualism and Collectivism: Theory, Method, and Applications (pp. 85-119), Thousand Oaks, CA: Sage.

Schwartz, S. H. (2006), 'A Theory of Cultural Value Orientations: Explication and Applications', Comparative Sociology, 5(2-3): 137-82.

Schwartz, S. H. (2011), 'Values: Cultural and Individual', In F. J. R van de Vijver, Chasiotis, A., and Breugelmans, S. M. (Eds), Fundamental Questions in Cross-Cultural Psychology (pp. 463-493), Cambridge: Cambridge University Press.

Shane, S. (1993), 'Cultural Influences on National Rates of Innovation', Journal of Business Venturing, 8(1): 59-73.

Shane, S. A. (1992), 'Why Do Some Societies Invent More Than Others?', Journal of Business Venturing, 7(1): 29-46. 
Stephan, U., and Pathak, S. (2016), 'Beyond Cultural Values?: Cultural Leadership Ideals and Entrepreneurship', Journal of Business Venturing, 31(5): 505-523.

Stephan, U., and Uhlaner, L. (2010), 'Performance-Based vs. Socially Supportive Culture: A Cross-National Study of Descriptive Norms and Entrepreneurship', Journal of International Business Studies, 41(8): 1347-1364.

Storr, V. H. (2004), Enterprising Slaves and Master Pirates: Understanding Economic Life in the Bahamas, Bern: Peter Lang.

Storr, V. H. (2013), Understanding the Culture of Markets, New York: Routledge.

Storr, V., and John, A. (2020), Cultural Considerations within Austrian Economics, Cambridge: Cambridge University Press.

Taras, V., Rowney, J., and Steel, P. (2009), 'Half a Century of Measuring Culture: Review of Approaches, Challenges, and Limitations Based on the Analysis of 121 Instruments for Quantifying Culture', Journal of International Management, 15(4): 357-373.

Taylor, M. Z., and Wilson, S. (2012), 'Does Culture Still Matter?: The Effects of Individualism on National Innovation Rates', Journal of Business Venturing, 27(2): 234-247.

Teague, M. V., Storr, V. H., and Fike, R. (2020), 'Economic Freedom and Materialism: an Empirical Analysis', Constitutional Political Economy, 31(1): 1-44.

Thai, M. T. T., and Turkina, E. (2014), 'Macro-Level Determinants of Formal Entrepreneurship versus Informal Entrepreneurship, Journal of Business Venturing, 29(4): 490-510.

The Heritage Foundation (2020), 2020 Index of Economic Freedom. Methodology. https://www.heritage.org/index/pdf/2019/book/methodology.pdf

Trompenaars, A., and Hampden-Turner, C. (1997), Riding the Waves of Culture: Understanding Cultural Diversity in Business, London: Nicholas Brealey Publishing.

Valdez, M. E., and Richardson, J. (2013), 'Institutional Determinants of Macro-Level Entrepreneurship', Entrepreneurship Theory and Practice, 37(5): 1149-1175.

Wennberg, K., Pathak, S., and Autio, E. (2013), 'How Culture Moulds the Effects of Self-Efficacy and Fear of Failure on Entrepreneurship', Entrepreneurship and Regional Development, 25(9-10): 756-780.

Wennekers, S., Van Wennekers, A., Thurik, R., and Reynolds, P. (2005), 'Nascent Entrepreneurship and the Level of Economic Development'. Small Business Economics, 24(3): 293-309.

Williamson, O. E. (2000), 'The New Institutional Economics: Taking Stock, Looking Ahead, Journal of Economic Literature, 38(3): 595-613.

WVS (2015), World Value Survey 1981-2014 Longitudinal Aggregate v.20150418. World Values Survey Association (www.worldvaluessurvey.org), Aggregate File Producer: JDSystems Data Archive, Madrid, Spain. 


\section{Table 1. Definitions of variables and descriptive statistics}

Variables

Mean Std. Dev.

Dependent:

Actively involved in start-up effort as owner (nascent entrepreneur, GEM definition) $=1, \quad 0.06 \quad 0.23$ otherwise 0

GEM-based, individual-level explanatory variables

Age of respondent in years

$42.41 \quad 15.13$

Male respondent $=1$, female $=0$

$0.48 \quad 0.50$

4 educational categories (no education beyond primary taken as benchmark)

Some secondary education $=1$

$0.25 \quad 0.43$

Secondary education $=1$

$0.33 \quad 0.47$

Tertiary education $=1$

$0.36 \quad 0.48$

3 head of household income categories (benchmark: low income):

Middle income (middle $33 \%$ of distribution) $=1$

$0.34 \quad 0.47$

High income (high $33 \%$ of distribution) $=1$

$0.33 \quad 0.47$

Owner-manager of established business (more than 42 months old) $=1 \quad 0.07 \quad 0.26$

Discontinued, sold or shot down a business in last 12 months $=1 \quad 0.04 \quad 0.19$

Business angel (within last three years personally provided funding for new businesses) $=1 \quad 0.04 \quad 0.20$

Have the knowledge, skill and experience required to start a new business $=1 \quad 0.49 \quad 0.50$

Fear of failure would prevent you from starting a business $=1$

$0.38 \quad 0.49$

Non-GEM based, country-year level explanatory variables

Effective constraints on the executive branch of the government (Polity IV)

$5.88 \quad 6.71$

Business freedom index (Heritage Foundation / Wall Street Journal)

$72.53 \quad 13.80$

Gross domestic product p.c. constant prices, purchasing power parity, $\mathrm{k} \$$ (World Bank) $\quad 25.13 \quad 14.22$

Unemployment rate (World Bank)

$8.67 \quad 5.54$

Schwartz value indicators, country-year level means (World Value Survey):

Important to think up new ideas and be creative (H1)

$4.24 \quad 0.31$

Important to live in secure surroundings (H2)

$4.50 \quad 0.45$

Important to always behave properly

$4.38 \quad 0.42$

Important: tradition

$\begin{array}{ll}4.36 & 0.49\end{array}$

Important: adventure and taking risks

$3.19 \quad 0.47$

Important to be rich

$2.89 \quad 0.63$

Important to be very successful

$3.87 \quad 0.50$

Important to have a good time

$3.86 \quad 0.49$

Important to look after the environment

$4.55 \quad 0.33$ 
Table 2. Estimation results

\begin{tabular}{|c|c|c|c|c|}
\hline Dependent: being engaged in a (nascent) startup & $(1)$ & $(2)$ & (3) & $(4)$ \\
\hline VARIABLES & $\begin{array}{l}\text { Random } \\
\text { intercept }\end{array}$ & $\begin{array}{c}\text { Random slope: } \\
\text { education }\end{array}$ & $\begin{array}{c}\text { Random } \\
\text { slope: gender }\end{array}$ & $\begin{array}{l}\text { Random } \\
\text { slope: age }\end{array}$ \\
\hline Age & $\begin{array}{c}0.99 * * * \\
(0.00) \\
\end{array}$ & $\begin{array}{c}0.99 * * * \\
(0.00) \\
\end{array}$ & $\begin{array}{c}0.99^{* * *} \\
(0.00) \\
\end{array}$ & $\begin{array}{c}0.99 * * * \\
(0.00) \\
\end{array}$ \\
\hline Age squared & $\begin{array}{c}1.00^{* * *} \\
(0.00)\end{array}$ & $\begin{array}{c}1.00^{* * *} \\
(0.00) \\
\end{array}$ & $\begin{array}{c}1.00 * * * \\
(0.00)\end{array}$ & $\begin{array}{c}1.00^{* * * *} \\
(0.00)\end{array}$ \\
\hline Male & $\begin{array}{c}1.27 * * * \\
(0.03)\end{array}$ & $\begin{array}{c}1.28^{* * *} \\
(0.03)\end{array}$ & $\begin{array}{c}1.40^{* * *} \\
(0.13)\end{array}$ & $\begin{array}{c}1.27 * * * \\
(0.03)\end{array}$ \\
\hline Education $=$ Secondary & $\begin{array}{c}0.88^{* * *} \\
(0.02)\end{array}$ & $\begin{array}{c}0.87 \\
(0.08)\end{array}$ & $\begin{array}{c}0.88^{* * * *} \\
(0.02)\end{array}$ & $\begin{array}{c}0.89 * * * \\
(0.02) \\
\end{array}$ \\
\hline Education $=$ Some secondary & $\begin{array}{c}0.83 * * * \\
(0.03) \\
\end{array}$ & $\begin{array}{l}0.82 * \\
(0.08) \\
\end{array}$ & $\begin{array}{c}0.82 * * * \\
(0.03) \\
\end{array}$ & $\begin{array}{c}0.84 * * * \\
(0.03) \\
\end{array}$ \\
\hline Education $=$ Primary or less & $\begin{array}{c}0.74 * * * \\
(0.03)\end{array}$ & $\begin{array}{l}0.77^{*} \\
(0.09)\end{array}$ & $\begin{array}{c}0.74 * * * \\
(0.03) \\
\end{array}$ & $\begin{array}{c}0.74 * * * \\
(0.03)\end{array}$ \\
\hline Medium Income & $\begin{array}{c}0.96 \\
(0.03) \\
\end{array}$ & $\begin{array}{c}0.96 \\
(0.03)\end{array}$ & $\begin{array}{c}0.96 \\
(0.03)\end{array}$ & $\begin{array}{c}0.97 \\
(0.03)\end{array}$ \\
\hline High Income & $\begin{array}{l}1.05+ \\
(0.03)\end{array}$ & $\begin{array}{l}1.05+ \\
(0.03)\end{array}$ & $\begin{array}{l}1.06+ \\
(0.03) \\
\end{array}$ & $\begin{array}{l}1.07^{*} \\
(0.03) \\
\end{array}$ \\
\hline Manages and owns a business that is older than 42 months & $\begin{array}{c}0.45^{* * *} \\
(0.02)\end{array}$ & $\begin{array}{c}0.45^{* * *} \\
(0.02)\end{array}$ & $\begin{array}{c}0.44^{* * *} \\
(0.02)\end{array}$ & $\begin{array}{c}0.45^{* * *} \\
(0.02)\end{array}$ \\
\hline In the past 12 months, discontinued a business & $\begin{array}{c}1.41^{* * *} \\
(0.05)\end{array}$ & $\begin{array}{c}1.41^{* * *} \\
(0.05)\end{array}$ & $\begin{array}{c}1.39 * * * \\
(0.05)\end{array}$ & $\begin{array}{c}1.42 * * * \\
(0.05)\end{array}$ \\
\hline In the past 3 years, provided funds for a new business & $\begin{array}{c}1.49^{* * *} \\
(0.05)\end{array}$ & $\begin{array}{c}1.49^{* * *} \\
(0.05)\end{array}$ & $\begin{array}{c}1.49^{* * *} \\
(0.05)\end{array}$ & $\begin{array}{c}1.52^{* * *} \\
(0.05)\end{array}$ \\
\hline $\begin{array}{l}\text { Have knowledge, skill and experience to start a new } \\
\text { business }\end{array}$ & $\begin{array}{c}4.51^{* * *} \\
(0.13)\end{array}$ & $\begin{array}{c}4.52 * * * \\
(0.13)\end{array}$ & $\begin{array}{c}4.48 * * * \\
(0.13)\end{array}$ & $\begin{array}{c}4.59 * * * \\
(0.13) \\
\end{array}$ \\
\hline Fear of failure would prevent you from starting a business & $\begin{array}{c}0.71^{* * *} \\
(0.02)\end{array}$ & $\begin{array}{c}0.72^{* * *} \\
(0.02)\end{array}$ & $\begin{array}{c}0.71^{* * *} \\
(0.02)\end{array}$ & $\begin{array}{c}0.72^{* * *} \\
(0.02)\end{array}$ \\
\hline GDP per capita (constant 2011 PPP, lagged) & $\begin{array}{c}0.97 * * * \\
(0.01)\end{array}$ & $\begin{array}{c}0.97^{* * *} \\
(0.00)\end{array}$ & $\begin{array}{l}0.97^{* * *} \\
(0.01)\end{array}$ & $\begin{array}{c}0.97^{* * *} \\
(0.00)\end{array}$ \\
\hline GDP per capita, squared (constant 2011 PPP, lagged) & $\begin{array}{c}1.00^{* * *} \\
(0.00)\end{array}$ & $\begin{array}{c}1.00^{* * *} \\
(0.00)\end{array}$ & $\begin{array}{c}1.00^{* * *} \\
(0.00)\end{array}$ & $\begin{array}{c}1.00^{* * *} \\
(0.00)\end{array}$ \\
\hline Unemployment rate (lagged) & $\begin{array}{c}0.98 \\
(0.01)\end{array}$ & $\begin{array}{l}0.98^{* *} \\
(0.01)\end{array}$ & $\begin{array}{c}0.98 \\
(0.01)\end{array}$ & $\begin{array}{c}0.98^{* * *} \\
(0.01)\end{array}$ \\
\hline $\begin{array}{l}\text { Constraints on the executive branch of government } \\
\text { (lagged) }\end{array}$ & $\begin{array}{c}0.99 \\
(0.06) \\
\end{array}$ & $\begin{array}{c}0.97 \\
(0.03) \\
\end{array}$ & $\begin{array}{c}0.99 \\
(0.04) \\
\end{array}$ & $\begin{array}{c}1.00 \\
(0.02) \\
\end{array}$ \\
\hline Business freedom (lagged) & $\begin{array}{l}1.00 \\
(0.01)\end{array}$ & $\begin{array}{l}1.00 \\
(0.00)\end{array}$ & $\begin{array}{c}1.00 \\
(0.00) \\
\end{array}$ & $\begin{array}{c}1.00 \\
(0.00)\end{array}$ \\
\hline Important think up new ideas and be creative (mean) & $\begin{array}{l}1.62+ \\
(0.46)\end{array}$ & $\begin{array}{c}1.84 * * * \\
(0.32)\end{array}$ & $\begin{array}{l}1.63^{*} \\
(0.37)\end{array}$ & $\begin{array}{c}1.70^{* * *} \\
(0.20)\end{array}$ \\
\hline Important to be rich (mean) & $\begin{array}{c}0.77 \\
(0.14)\end{array}$ & $\begin{array}{l}0.74 * * \\
(0.08)\end{array}$ & $\begin{array}{l}0.75^{*} \\
(0.11) \\
\end{array}$ & $\begin{array}{c}0.71^{* * *} \\
(0.05)\end{array}$ \\
\hline Important to live in secure surroundings (mean) & $\begin{array}{l}1.40+ \\
(0.28)\end{array}$ & $\begin{array}{l}1.37^{*} \\
(0.17)\end{array}$ & $\begin{array}{l}1.46^{*} \\
(0.24)\end{array}$ & $\begin{array}{c}1.45^{* * *} \\
(0.12)\end{array}$ \\
\hline Important to have a good time (mean) & 0.99 & 0.99 & 0.94 & 0.95 \\
\hline
\end{tabular}




\begin{tabular}{|c|c|c|c|c|}
\hline & $(0.12)$ & $(0.08)$ & $(0.09)$ & $(0.05)$ \\
\hline Important to be very successful (mean) & $\begin{array}{c}0.81 \\
(0.18) \\
\end{array}$ & $\begin{array}{c}0.84 \\
(0.12) \\
\end{array}$ & $\begin{array}{c}0.82 \\
(0.15) \\
\end{array}$ & $\begin{array}{c}0.88 \\
(0.08) \\
\end{array}$ \\
\hline Important: adventure and taking risks (mean) & $\begin{array}{c}1.19 \\
(0.22) \\
\end{array}$ & $\begin{array}{c}1.20 \\
(0.14) \\
\end{array}$ & $\begin{array}{c}1.22 \\
(0.18) \\
\end{array}$ & $\begin{array}{l}1.26^{* *} \\
(0.10) \\
\end{array}$ \\
\hline Important to always behave properly (mean) & $\begin{array}{c}1.04 \\
(0.28) \\
\end{array}$ & $\begin{array}{c}1.04 \\
(0.18) \\
\end{array}$ & $\begin{array}{c}0.94 \\
(0.21) \\
\end{array}$ & $\begin{array}{c}0.99 \\
(0.11) \\
\end{array}$ \\
\hline Important to look after the environment (mean) & $\begin{array}{l}0.59+ \\
(0.17) \\
\end{array}$ & $\begin{array}{c}0.53 * * * \\
(0.09)\end{array}$ & $\begin{array}{l}0.60 * \\
(0.14) \\
\end{array}$ & $\begin{array}{c}0.53 * * * \\
(0.06)\end{array}$ \\
\hline Important: tradition (mean) & $\begin{array}{c}0.93 \\
(0.21) \\
\end{array}$ & $\begin{array}{c}0.92 \\
(0.13)\end{array}$ & $\begin{array}{c}0.95 \\
(0.17)\end{array}$ & $\begin{array}{c}0.92 \\
(0.09) \\
\end{array}$ \\
\hline Constant & $\begin{array}{c}0.03 * * * \\
(0.00)\end{array}$ & $\begin{array}{c}0.03 * * * \\
(0.00)\end{array}$ & $\begin{array}{c}0.02 * * * \\
(0.00)\end{array}$ & $\begin{array}{c}0.03 * * * \\
(0.00)\end{array}$ \\
\hline Variance of the random term & $\begin{array}{c}1.22 * * * \\
(0.04)\end{array}$ & $\begin{array}{c}1.24 * * * \\
(0.03)\end{array}$ & $\begin{array}{c}1.28 * * * \\
(0.04)\end{array}$ & $\begin{array}{c}1.26 * * * \\
(0.02)\end{array}$ \\
\hline Observations & 157,806 & 157,806 & 157,806 & 157,806 \\
\hline Number of groups & 69 & 69 & 69 & 69 \\
\hline
\end{tabular}

Notes:

Odds ratios reported instead of coefficients.

Exponentiated standard errors reported in brackets.

$* * * \mathrm{p}<0.001, * * \mathrm{p}<0.01, * \mathrm{p}<0.05,+\mathrm{p}<0.10$ 